\title{
BRF2 wt Allele
}

National Cancer Institute

\section{Source}

National Cancer Institute. BRF2 wt Allele. NCI Thesaurus. Code C52626.

Human BRF2 wild-type allele is located in the vicinity of $8 \mathrm{p} 12$ and is approximately $6 \mathrm{~kb}$ in length. This allele, which encodes RNA polymerase III transcription initiation factor BRFU protein, is involved in the promotion of transcription for nuclear RNAs. 